\title{
Fathers on Leave: Experiences of Middle-Class Fathers on Parental Leave in the City of Zagreb
}

\author{
MIRNA VARGA* \\ Association for Creative Social Work \\ Zagreb, Croatia
}

\author{
Original scientific paper \\ UDK: 349.2-055.1(,ZZagreb“) \\ doi: $10.3935 /$ rsp.v28i3.1807 \\ Received: February 2021
}

\begin{abstract}
Parental leave reforms that aimed at higher father's involvement in childcare began in the 1970s. However, the number of fathers who took parental leave increased only in the 1990s when Scandinavian countries began introducing father's quotas or paternity leaves, that is, earmarked leave periods to be used by fathers or otherwise lost. Croatia introduced the two-month father's quota as late as in 2013. Although the reform did not contribute to a sudden increase in the number of fathers on parental leave, there is always a steady, albeit small, number of fathers taking up leave. This article aims to provide an insight into fathers' experiences on parental leave in Croatia. Relying on interviews with 11 middle-class fathers in the City of Zagreb, the article explores father's motives for taking leave, their experience regarding the initial decision and the procedure of exercising their right to leave and their experience of being on leave. Results suggest that the fathers were very eager to use their right to leave and spend time with their children. They mostly used longer leaves (more than 3 months) and the experience of being home alone with the child made the fathers learn new skills in relation to childcare and housework, but also rethink their relation to work and family.
\end{abstract}

Key words: parental leave policy, parental leave, father's quotas, fathers' experiences, Croatia.

\section{INTRODUCTION}

There is a growing awareness within European societies that in order to foster gender equality in the labour market we need to have gender equality at home. Therefore, if we want women to be more engaged in the labour market, we need men to engage more in childcare and housework. It is an issue of work-life balance. Many women have at least some difficulty managing work and care since they are still expected to devote more time to housework and childcare than men are. This creates unequal opportunities for women in the labour market. For example, it is more likely that women will adapt their working hours or withdraw from the labour market due to childcare (OECD, 2011; Huerta et al.,

\footnotetext{
* Mirna Varga, Association for Creative Social Work / Udruga za kreativni socijalni rad, Lopatinečka ulica 17 , 10000 Zagreb, Hrvatska / Croatia, mirna.varga@uksr.hr
} 
2013). These kinds of behaviours endorse expectations that women will use parenting leaves ${ }^{1}$ and be absent from work, which may prompt employers to discriminate against female workers by investing more in their male counterparts (Farré, 2016). With the aim of establishing more equality in the public and private spheres, parental leave policies have been changing, encouraging higher fathers' involvement in childcare. A breakthrough happened when Scandinavian countries introduced a quota system, that is, an earmarked period of parental leave to be used by fathers or otherwise lost (O'Brien, 2009). For example, in Norway, the first country to implement quotas in 1993, only $3 \%$ of fathers exercised their right to leave before the quota system. After the quota system was introduced there was a significant increase in the number of fathers taking leave $-60 \%$ of them in 1995 (Rege and Solli, 2013). It is estimated that nowadays around $90 \%$ of eligible fathers in Norway take at least some portion of leave (Bungum and Kvande, 2020).

While Croatian legislation provides both parents with an individual right to parental leave, women are still taking all or a great majority of leave in practice. In 2013 a quota system was integrated into the parental leave policy design to encourage more men to take leave. However, in the first five years since the quota was implemented, the share of fathers using this opportunity seemed to stagnate at around $4.5 \%$ of all leave takers (Annual Report of the Ombudsperson for Gender Equality of the Republic of Croatia, 2020). Fathers' involvement in childcare can be viewed from a broader perspective of the gender distribution of care work. Getting fathers involved in childcare is considered an innovative approach to changes in the gen- der understanding of parental responsibilities (Doucet, 2017). Against that backdrop, this research was designed to investigate what motivated fathers in Croatia's capital to use parental leave and to get an insight into their experiences while being on leave, with a particular focus on leave policy design elements having a potential to increase fathers' take-up rates. Before presenting the research results, this article provides a brief overview of the determinants and outcomes of fathers' use of leave and parenting leaves in Croatia.

\section{DETERMINANTS AND OUTCOMES OF FATHERS' USE OF LEAVE}

Differences in fathers' use of leave in various countries suggest that the leave policy design, as well as work environment and specific personal characteristics of fathers, influence fathers' decision to use leave. The quota system showed that fathers are inclined to use earmarked leaves, that is, leaves that are non-transferable and fairly compensated with a generous replacement rate (Brandth and Kvande, 2009; O'Brien, 2009; Huerta et al., 2013; Koslowski et al., 2020). Referring to fathers' socioeconomic status, it is higher for leave takers than fathers who did not take leave. Leave takers had higher education, higher incomes, worked full-time and were married (Huerta et al, 2013.). Research is consistent in saying that more educated fathers are more prone to leave-taking (Nepomnyaschy and Waldfogel, 2007; Geisler and Kreyenfeld, 2011, Wall and Leitão, 2017). Another critical determinant in the decision-making process are fathers' personal preferences. Fathers say that their motivation behind using leave was to spend time and create an emotional

\footnotetext{
${ }^{1}$ Parenting leaves is an umbrella term used here for maternity, paternity and parental leave. Maternity leave is the right of the mother and paternity leave is the right of the father (or other carer), whereas parental leave is the right of both parents. Parental leave legislation may include earmarked and non-transferable portions of leave (a few weeks/months), which are most commonly known as father's quotas (Dobrotić, 2015).
} 
bond with the child, but also to enjoy parenthood as a shared endeavour with the mother (Meil et al., 2017, Wall and Leitão, 2017; Tremblay and Lazzari Dodeler, 2017; Duvander et al., 2017). In addition to these, fathers need supportive work environments to realise their right to leave in a desired way. In countries where fathers' use of leave has long been encouraged and normalised, fathers face no negative consequences in the workplace (for Iceland see Gíslason, 2017, for Norway see Kvande and Brandth, 2017). However, in countries that have only started implementing fathers' leave in the last decade or so, fathers find themselves having to negotiate (for Portugal see Wall and Leitão, 2017) or justify their use of leave (for Spain see Meil et al., 2017).

Child-rearing can enhance fathers' quality of life through changes in their perceptions of masculinity and fatherhood, allowing them to develop emotionality and a sense of care (Korsvik and Warat, 2016). This means that higher fathers' involvement in housework and childcare while on leave can lead to a more egalitarian division of work at home, thus unburdening mothers who have been traditionally perceived as carers. For such changes to happen, and last, fathers should spend a certain amount of time on leave. The following paragraphs provide a brief overview of the outcomes of fathers' use of leave regarding the child, father-child relationship, and fathers alone (for a more extensive overview see Dobrotić and Varga, 2018).

Research is conclusive in saying that fathers' use of leave contributes to fathers' later involvement in childcare (Nepomnyaschy and Waldfogel, 2007; Tanaka and Waldfogel, 2007, Haas and Hwang, 2008, Brandth and Kvande, 2009; McKay and Doucet, 2010; Huerta et al., 2013; Almqvist and Duvander, 2014). However, fathers should use leave for a certain period for a lasting effect. Some research indicates that fathers who spend over two weeks on leave are more engaged in childcare-related activities (e.g. feeding, changing diapers, waking up at night, bathing and reading books) than those who did not take leave (Huerta et al., 2013). Contributions by several qualitative research studies done with 'fathers on leave alone' suggest that taking leave for a longer period of time (beyond 1 or 2 months) strongly impacts both the lived experiences and negotiation of parental roles. This means that fathers start identifying with mothers who take long leaves, but also feel more confident and assertive in assuming equal and individualised parenting routines (O'Brien and Wall, 2017). Parents also report that the child responds equally to both mother and father in situations when fathers took longer leaves (Almqvist and Duvander, 2014; Kvande and Brandth, 2017).

However, an important precondition for change regarding fathers' use of leave is "being on leave alone", that is, without the mother or another adult. In situations where fathers take leave together with the mother they do not perceive their role as very significant, nor does such leave-taking result in changed attitudes towards gender roles. Those fathers see themselves as "helpers" and resort to mothers to "interpret" the child's needs to them. On the contrary, fathers who spend "leave alone" report that they have developed childcare competencies and enhanced their sensitivity towards the child, that is, the capability to understand the child's needs. This made them feel more competent as parents. They became more attentive and open to allowing the child's needs to determine the course of the daily routine (Kvande and Brandth, 2017; Wall and Leitão, 2017, Tremblay and Lazzari Dodeler, 2017; Meil et al., 2017; Duvander et al., 2017; Valarino, 2017). Another change observed in the case of fathers who spent at least one month on leave relates to a newfound understanding of the work mothers $d o$, both concerning the household and childcare. For example, these fathers 
performed care work and they cooked and cleaned daily, which resulted in fathers being sleep deprived and feeling exhausted and lonely (Kvande and Brandth, 2017; Wall and Leitão, 2017; Tremblay and Lazzari Dodeler, 2017; Lammi-Taskula, 2017).

The outcome of fathers' use of leave on gender equality and gender roles is two-dimensional and can be perceived through the gendered division of housework and caring responsibilities. Regarding childcare, fathers in Portugal seemed to be contesting traditional gender roles through the realisation that caring for a child is a learnable skill and not an inherent ability of the mother. These fathers started perceiving themselves as equal carers who negotiated and agreed on childcare responsibilities together with the mother (Wall and Leitão, 2017). In Switzerland, fathers perceived leave as a necessary time to establish their role as fathers, to "be present" with and bond with the child. They said it was precisely the transformation of gender roles that enabled them to develop a more engaged, caring and warm-hearted relationship with their children, as opposed to relationships that previous generations had with their children (Valarino and Gauthier, 2016). In addition to being more involved in childcare, fathers who take longer leaves engage more in housework, even though fathers are less prone to engaging in housework than in childcare (Almqvist and Duvander, 2014). Higher involvement in housework is observed in fathers who spent two months on leave, but also in fathers who were on "leave alone" (Bünning, 2015).

\section{PARENTING LEAVES IN CROATIA}

Croatia has a mixed leave system, that is, a leave system which combines employment-based and citizenship-based leave entitlements. (Self)employed parents who meet the condition of at least nine months of continuous social insurance or twelve months with interruptions in the previous two years are eligible for earnings-related leave benefits, while all other parents who do not meet these criteria are eligible for a low, flat-rate citizenship-based leave benefit (Dobrotić and Blum, 2020).

Parents are granted the rights to maternity and parental leave. Maternity leave lasts from 28 (or exceptionally 45) days prior to the expected date of birth until the child turns six months of age. Mothers are obliged to take the first 98 days (28 days before and 70 days after birth) and they can transfer the remaining days to the father. While on maternity leave, and if fulfilling the previously mentioned insurance period criteria, the parent is granted $100 \%$ of previous earnings ${ }^{2}$, with no ceiling on payments. (Self)employed parents who do not fulfil employment-based eligibility criteria or unemployed/inactive parents are entitled to a low, flat-rate benefit (2 328 HRK per month; 310 EUR) (Maternity and Parental Benefits Act, NN 54/13, 59/17, 37/20, Art. 12 and 24).

Parental leave is an individual entitlement and can be used after maternity leave until the child is eight years old. The duration of parental leave is eight months (4 months per (self)employed parent) for the first and second-born child, with two months being non-transferable. This means that one parent can use up to six months of parental leave and two non-transferable months are lost if the leave is not used by both parents (Maternity and Parental Benefits Act, NN 54/13, 59/17, 37/20, Art. 12 and 14). This quota system was implemented in 2013 and it refers only to the first or second child and dual-earner families. In the case of multiple births or birth of a third or any subsequent child, the overall duration of pa-

\footnotetext{
${ }^{2}$ The benefit level is calculated based on the earnings in the period of six months before the leave started
} 
rental leave can be extended to 30 months (15 months per parent, all transferable) (Dobrotić and Varga, 2018). Parental leave benefit for (self)employed parents fulfilling employment-based criteria is also calculated on previous earnings; however, there is a ceiling set at $170 \%$ of budgetary base rate (5,654 HRK; 748 EUR) $)^{3}$.

Parents can choose the leave modality, that is, they can use parental leave at once (fully) or in parts. In the latter case, it can be taken no more than twice a year and each time for no less than 30 days. Both maternity (after the first 98 days) and parental leave can be used part-time (Maternity and Parental Benefits Act, NN 54/13, 59/17, 37/20, Art. 15).

When this research was conducted (in 2018) the highest parental benefit (self) employed parents could receive was 3991 HRK per month (537 EUR). This amounted to $64 \%$ of the then average net pay in Croatia. In the 2013-2017 period the share of fathers in the overall number of parental leave takers was stagnating at around $4.5 \%$. With the benefit increase in 2017, the number of fathers had almost doubled, reaching in $20198.71 \%$ of fathers in the overall number of leave takers (Annual Report of the Ombudsperson for Gender Equality of the Republic of Croatia, 2020.). As mentioned earlier, fathers use leaves that are earmarked, non-transferable and fairly compensated (Brandth and Kvande, 2009; O'Brien, 2009; Huerta et al., 2013; Koslowski et al., 2020). Besides leave design, socioeconomic factors and workplace culture are other factors that contribute to or hinder fathers' use of leave, and particularly the prevailing societal attitudes towards mothering (for an extensive overview see Dobrotić and Varga, 2018). Lammi-Taskula (2006; Burnett et al., 2013) argues that attempts to implement fathers-only' leaves and encourage fathers to use them are inclined to fail if general societal attitudes require mothers to be visible carers for children, thus hindering prospects of fathers' greater involvement. Research in Croatia shows that almost half of both female and male respondents (around 49\%) believe that the mother should use the entirety of leave and spend a total of 12 months at home with a new-born (Jugović, 2016). In addition to prevailing attitudes, Croatia still hasn't implemented paternity leave - the right of fathers to care for a new-born around the time of birth (Dobrotić, 2015).

\section{RESEARCH METHODOLOGY}

Given the fact that a very small number of fathers take parental leaves in Croatia and bearing in mind the prevailing attitudes regarding the distribution of leave between partners, this research was designed to understand the motivation behind fathers' use of leave and get an insight into their experiences while on leave, with a special focus on the leave scheme design. Three overall research questions were designed:

1. What were the motives behind fathers' use of leave?

2. What were the fathers' experiences regarding the initial decision and procedure of exercising their right to leave?

3. What were the fathers' experiences during the leave period?

The target group of this research were fathers who used parental (and/or mater-

\footnotetext{
${ }^{3}$ The upper ceiling has changed recently and as of April 2020 (the last increase) amounts to 5654 HRK per month (748 EUR). This amount is much closer to the average net earnings in Croatia (7 175 HRK or 956 EUR) (Croatian bureau of statistics, 2021u). Until 2017 the ceiling was at $80 \%$ of budgetary base rate (2 $660 \mathrm{HRK}$ per month; 358 EUR), to be raised in 2017 at 120\% of budgetary base rate (3 991 HRK; 537 EUR). The following year (2018) was the first year that saw notable increase in fathers' uptake of parental leave (Annual Report of the Ombudsperson for Gender Equality of the Republic of Croatia, 2020).
} 
nity) leave for at least one month, with the condition of residing in the City of Zagreb. Zagreb is among the cities with the highest living standard in Croatia and offers additional financial support to its residents in the event of childbirth. Parents in Zagreb can also rely on various other services and types of support, not always accessible to those living in smaller cities. Moreover, research shows that residents of Zagreb (and Istria and Kvarner) hold more egalitarian values towards gender roles than those in the rest of Croatia (Baloban et al., 2019). This is also reflected in the fact that men in Zagreb tend to do more housework than men in the rest of Croatia (Tomić-Koludrović et al., 2018) Therefore, it was expected to come across a higher incidence of fathers who used leave and were willing to share their experiences in Zagreb.

Even though no other condition was required for sampling purposes, apart from residence and having spent one month on leave, the sample eventually consisted of 11 middle-class fathers. That is, fathers with higher education, whose partners also had higher education and who lived in dual-earner families with stable and steady incomes. The sample characteristic is not surprising as in Croatia only dual-earner families are entitled to the father's quota. The previous studies also showed that fathers with higher socioeconomic status are more prone to use leave (Huerta et al., 2013). It may be that middle-class fathers are more aware of gender equality issues and the challenging task of balancing work and family life and are more informed about their rights to leave and lean towards a dual-earner/dual carer model. However, it may also be that middle-class fathers can afford to take leave, unlike the rest who cannot afford to minimise their income while on leave. Although it is hard to say whether this sample's characteristics match reality, the sample can be perceived as a critical case. Flyvbjerg (2006: 14) defines a critical case as "having strategic importance in relation to the general problem". As experiences of fathers who took leave in Croatia have not yet been researched, data presented here can be seen as the first step towards understanding a bigger picture around their leave-taking and experience. Therefore, the findings should be taken as indicative, rather than representative.

Due to a very small number of fathers who take leave, various sampling strategies were used to reach fathers. Several fathers were initially reached out to through personal contacts and the sample snowballed from there, as some fathers knew other fathers who had taken leave and were willing to be a part of this research. The sample's shared socioeconomic characteristics may be the consequence of such a recruitment process. Additionally, information about the research and a call to take part in the study was published on a Facebook page of "Roda" (Roditelji u akciji - Parents in action), a civic society organisation based in Zagreb that provides information and support to parents in Croatia and is very engaged in encouraging fathers to get involved in childcare. However, there were no responses from fathers through this channel.

The sample consisted of 11 fathers who used leave. All the fathers, except for one, used leave in the period until the child turned three, following the mother's end of leave. One father used leave when the child started school at the age of seven and his experience differs insofar as his main motivation to use leave was to support the child in transition from kindergarten to school. Fathers mostly used longer leaves, ranging from 3 up to 34 months. Six fathers had one child, while the rest had either two or three children and they used leave multiple times for different children. Eight fathers used leave for four or more months. The average age of fathers in this research was 41.5. Fathers and their partners mostly have higher education - nine fathers and eight partners. 
One father was single, one was living in an extramarital union, while the rest were married. At the time of research, all of the fathers were working full time, with two of them working in the public sector, while the rest worked in private companies. Only one father spent the leave together with the mother, while the rest were on leave alone. All the mothers were employed on a fulltime basis, with two mothers being self-employed. The latter's partners were among the fathers who took the longest leaves, implying that they were committed to supporting their partner's businesses.

The method used to conduct the research was a semi-structured interview. Such interviews allowed the researcher to ask questions based on important findings from the research done with fathers so far and cover the most important theoretical assumptions. In addition, they also provided enough space for fathers to share more than initially planned and allowed for the emergence of unanticipated new insights. Semi-structured interviews allowed for the emergence of precisely those themes that fathers deemed most important and relevant for the Croatian context. Fathers were asked about their motivation to use leave, reactions they received from people around them, the experience of being on leave, regarding both childcare and housework, and they were also asked what they thought about the leave scheme design that was in place at the time of research. The interview consisted of 15 questions with corresponding sub-questions.

Interviews were conducted between March and May of 2018. Getting fathers to agree to interviews took a certain amount of time and negotiation and almost all of the interviews took place in cafés in which fathers suggested we could meet for the interview. Only one interview was conducted in the father's home. Even though some interviews lasted more than an hour, the average duration was 50 minutes. All the interviews were audio-recorded. The participants' confidentiality was preserved since data containing their names or the names of their partners and children, as well as their workplace, is not listed anywhere in this paper. The data were anonymised so that the fathers' identities are not revealed. Fathers provided their informed consent and were told beforehand they had a right to withdraw from this research at any moment, which option none of the fathers used.

The method used to analyse the data obtained from interviews was thematic analysis. This research method was used in order to answer specific research questions and allow enough space for possible new findings not initially thought of. Because this topic is under-researched in the Croatian context and there are no research reports of this kind, this data analysis method was expected to suit the purpose of this research best. The data analysis wanted to capture those themes that showed to be most dominant (Braun and Clarke, 2006.). Following the thematic analysis procedure, firstly the responses that were found relevant for the theme and provided answers to the research questions were marked in the transcripts. The answers were then coded and grouped into themes. Finally, the themes were analysed in the contexts of the research questions.

\section{RESULTS: FATHERS' EXPERIENCES}

Findings are presented within four categories that correspond to the aforementioned research questions:

1. Motivation to use leave

2. Experiences regarding the initial decision and exercising the right to leave

3. Experiences while being on leave

4. Attitudes towards family and work

The motivation to use leave was analysed through: personal motives for using 
leave and additional factors in deciding to use leave. The experiences regarding the initial decision and exercising the right to leave were analysed through: the role of the leave scheme design in deciding to use leave and exercising the right to leave in the workplace and the Croatian health insurance fund (CHIF). Experiences while being on leave were analysed through: personal experience of being on leave, reactions fathers faced regarding their use of leave and support fathers relied on during leave. Lastly, attitudes towards family and work are reflected in attitudes towards parenthood, father-child relationship, housework and work.

\section{Motivation to use leave}

When analysing fathers' personal motives to use leave, the desire to be involved in the child's early upbringing was extracted as the only theme. It reflects the majority of fathers' attitudes of wanting to spend more time with the child. In contrast, a smaller number of fathers reported a sense of missing out (on being involved in the child's early upbringing) and a desire to bond with the child. Fathers who had their firstborn in their early thirties and who worked at demanding jobs that sometimes required overtime work were the ones emphasizing wanting to spend more time with the child. One such father explained his desire to be present with the child:

"That was the only reason. Just to be with her... I think it's important to be there, especially when she is still a small baby... when you work, you work from dusk 'til dawn, and you only get to see her for a small amount of time... When you're with her the whole day you get to see her when she's happy and when she's nervous." (Martin)

Fathers expressed a great desire to be there with the child and witness the moments when the child learns to crawl, walk or feed himself/herself. They wanted to experience and take on all the tasks related to caring. This kind of attitude is reported in numerous other research studies done with fathers who used leave. Spending time with the child and the consequent bonding have shown to be some of the most decisive motivating factors for fathers' use of leave (Wall and Leitão, 2017; Tremblay and Lazzari Dodeler, 2017; O’Brien and Twamley, 2017; Boyer, 2017).

Several themes were extracted as part of additional factors in deciding to use leave. Talking about splitting the leave between partners, a couple of fathers said they were asked to use a portion of leave by the mother, whereas some fathers were intrinsically motivated to share the leave with the mother on a more equal basis. The partners of the two fathers who were asked to use a portion of leave were self-employed and had a desire to return to work. The fathers intrinsically motivated to share leave expressed an eagerness to experience parenthood to the fullest. However, it was obvious from the interviews that the splitting of leave was a matter of a shared agreement between partners. This finding coincides with fathers' experiences in Portugal, who also expressed the desire to share leave as a motivating factor (Wall and Leitão, 2017). In Nordic countries, where fathers' use of leave is "taken for granted", splitting the leave is simply a matter of agreement between partners (Gíslason, 2017; Duvander et al., 2017). This "normalisation" of leave sharing can also be observed in fathers in this study who took longer leaves and agreed to do so with their partners.

to use leave was a desire to exercise their right to leave. That is, fathers were aware of having an individual right to leave. During interviews, many fathers (first-time fathers in their early thirties) mentioned that they thought many fathers were not informed about their rights and they believed this to be the reason why so many fathers 
never exercised their right to leave. Martin was again able to express that he was well informed and eager to exercise his legal entitlement:

"I kind of took one month from her (the mother), even though that's actually mine... I took one month from her and then two of my months... Everybody thinks that women get 12 months by default, but it's not 12. She gets 6 (referring to maternity leave) and then it's $4-4$, the parental leave, but most people don't know that... so, she basically spent almost a year with the baby even like this, but if the scheme was different then she would spend maybe 10 months and I would definitely spend at least my 2 months." (Martin)

Fathers were also keen on providing care for the child until the beginning of early childhood education and care (ECEC). This was reflected in postponing enrolment in ECEC and bridging the gap between the end of the mother's use of leave and the beginning of ECEC. The latter was evident in the cases of two fathers whose children turned one year old just before the summer, so they needed to find a childcare option until the autumn and the beginning of the new ECEC year. A recent research done in Zagreb also reports on bridging the gap until ECEC enrolment as motivation to use leave, suggesting that other fathers in Croatia are also inclined to use leave for this reason (Dobrotić, 2021). Some fathers from this research wanted to prolong ECEC enrolment for as long as possible and find alternative options until the child turns three. The practice of postponing ECEC enrolment was also observed in other European countries (for Portugal see Wall and Leitão, 2017, for Sweden see Duvander et al., 2017).

A couple of fathers, working in engineering and banking, stated professional reasons as motivating factors to use leave and talked about job saturation and a need to get away from work for a while. However, there was an exceptional case of one father who decided to use some time while on leave to start his own company. He was using leave for the third child, in which case leave can be used for 30 months, and relied on the wage replacement as a "safety net" in case that starting his own company fell through. There were also a couple of cases where the mother's professional reasons were decisive in the decision-making process, at least regarding the leave duration. This was the case for two fathers whose partners had businesses of their own and were eager to go back to work. Research in other countries reports an even greater incidence of mother's professional reasons influencing fathers' use of leave (Wall and Leitão, 2017; Tremblay and Lazzari Dodeler, 2017; Lammi-Taskula, 2017; Duvander et al., 2017). Taking longer leaves and thus supporting their partners in labour market integration would suggest that there are some shifts regarding gender equality, however, still conditioned by women's position in the labour market and their power to negotiate within the family.

\section{Experiences regarding the initial decision and procedure of exercising the right to leave}

The experiences regarding the initial decision and procedure of exercising the right to leave were analysed in the context of the leave scheme design, along with exercising the right at the Croatian health insurance fund (CHIF) and in the workplace. Findings show that the fathers came across certain challenges while exercising their rights at the CHIF, whereas exercising their rights in the workplace went relatively smoothly. This was evident for fathers working in large and stable companies, in high skilled jobs, with employers having little issues in filling the gap made by fathers' absence from their workplace. 
Changes in parental leave benefits took place in 2017, when the upper ceiling on the amount of the replacement rate was increased, and that became an incentive for two fathers to use leave. They were among a few fathers from the sample who were affected by this change and both of them said they would not have even considered taking leave had the parental benefit stayed the same:

"If they hadn't increased the parental benefit I would not have considered it. It wouldn't be enough... it's the best thing they did. You get something from the state, something from the city, so there is some money you can count on and get by with 3 990. If it was still 2800 I wouldn't go for sure. Maybe we could stretch it out somehow, but it would pose a real financial stress." (Petar)

This is yet another piece of evidence supporting the need for generous parental benefits, as they may encourage fathers to use leaves. Research clearly shows that fathers are more prone to use leave when it is an individual and non-transferable right, followed by a high replacement rate (Brandth and Kvande, 2009; O'Brien, 2009; Huerta et al., 2013).

Almost half of the fathers reported some challenges when exercising their right to leave at the CHIF. However, the other half reported undisturbed exercise of their rights. When it comes to difficulties in exercising the leave rights at the CHIF, fathers pointed out delays in receiving a formal decision on leave status, bureaucratization of the procedure for exercising the right to leave and, in the case of one father, an initial denial of the right to leave. The delay in receiving a decision on the leave status caused stress for fathers, as employers did not receive the formal decision from the CHIF before the official start of leave. Fathers perceived the bureaucratization of the procedure for exercising the leave right as unreasonable. It mostly referred to the amount of paperwork and unusual timeframes for making decisions. One father was visibly revolted because he could not use leave for as long as he would have liked to. Initially he was denied the right, and then granted three months and, only after he said he would sue the CHIF, he was granted four months of leave. This father was in his early fifties, worked in a public institution and was familiar with the functioning of the social security system. Therefore, he felt empowered to fight for his right:

"When I had done all that and mentioned the legal officer from my work, I came there later that afternoon and saw I got 4 months and I couldn't get 150 days because my wife used up 2 days out of 30 (rendering the rest of the days in the month's cycle unusable). So stupid! I think what hurt me the most is that their legal officer was making it sound like she was giving me something. Not that I have my right, but that she is being generous and giving me something." (Robert)

The question remains what happens to fathers who don't know their rights or don't feel empowered to act on their rights being infringed. The aforementioned case suggests that there may be cases of fathers who are denied their rights or made to use them in a way they did not initially intend to.

\section{Reflecting on exercising their right at} the workplace the majority of fathers reported uninterrupted exercise of the right to leave in the workplace. Some employers did not want to interfere with fathers' decision to take the leave due to reputational risk, while the rest looked at fathers' leave uptake with agreeability. Both fathers who mentioned reputational risk had stable jobs in banking. The rest of the fathers who exercised their right smoothly worked within both private and public sector, in large companies, but also in one small private 
business in hospitality. On the contrary, a few fathers reported employers' antagonism towards father's decision to use leave. The antagonism is reflected in employer's dissatisfaction with father's decision to use leave, difficulties in agreeing on the leave use with the employer and in the employer's attempt to discourage one father from taking the leave. It is worth noting, however, that a minority of fathers had slight issues with their employers regarding use of leave (which in their cases extended beyond the two month quota) and that those issues were encountered by fathers working in large private companies in different fields of work. These fathers exhibited a lot of awareness regarding their rights, which made them confident in negotiating their decision to take leave in the workplace. The same sense of entitlement was observed in fathers in Germany (Aunkofer et al., 2018). The following is a statement from a young father of one whose employer was not fully supportive of his decision to take leave:

"I announced it about six months earlier. He (employer) wasn't exactly pleased, but that was my legal entitlement and he enabled me to use it... It's not like he said not to go, but he kind of mumbled: if you really must." (Neven)

Fathers in Portugal also faced antagonism at the workplace towards their decision to use longer leaves. Employers were not entirely supportive of fathers' decisions to extend their leave beyond the two or four weeks of paternity leave (which is mandatory in Portugal). This put fathers in a position to negotiate taking leave at all (Wall and Leitão, 2017).

\section{Experiences while being on leave}

Experiences while being on leave were analysed through fathers' personal experience of being on leave, reactions fathers faced towards their use of leave and support fathers relied on during leave.
When discussing their personal experience of being on leave fathers reported a certain ambivalence insofar as leave was described as both exhausting and relaxing. Describing leave as an exhausting experience meant that fathers experienced fatigue over lack of sleep and described leave as a non-stop (fast) period. Fathers were somewhat surprised to learn that child-rearing requires constant alert and supervision. Martin, a first-time father who took 3 months of leave explained it as follows:

"Well, you first kind of expect something like a vacation: oh great, I'll have three months off. Then you realise it's a full time job and there's no downtime. You manage to light a cigarette only when she is asleep. You can't leave her alone over anything... you constantly have to watch over her, like an eagle." (Martin)

The fathers who spoke of exhaustion and leave being a fast period were the ones who took longer leaves ( 3 or more months) and also the ones who did most housework. Fathers in Norway who spent two or more months on leave also spoke of leave as being tiring and challenging (Kvande and Brandth, 2017). Fathers in other countries who spent "leave alone" and for more than one month also tended to describe leave as a "non-stop" period (for Portugal see Wall and Leitão, 2017, for Finland see Lammi-Taskula, 2017, for Switzerland see Valarino, 2017).

Apart from being exhausting, leave was also perceived as a peaceful and relaxing period, being described as pleasant and relaxing, but also fulfilling. Similar observations were noted in research with fathers in Sweden who talked about leave as a "bubble" of peace and rest from work (Duvander et al., 2017). It was also evident that the child's routine dictated the daily activities where fathers had to organise their day according to the child's needs. This is also 
supported by other research where fathers spoke of "slow time" and how they did not try to get much done, but simply took care of the child (Kvande and Brandth, 2017).

Half of the fathers regarded leave as a period of learning and acquiring new housework and childcare skills. The distinction between housework and acquiring skills in childcare was reflected in fathers' perception of housework as more difficult than caring for children. This is not surprising since studies indicate that fathers on leave are more inclined to care for children than involve in housework (Almqvist and Duvander, 2014). A father of three who used leave for all his children reflected on leave as a period of acquiring new skills in childcare, which he saw as a chance to grow and learn:

"You learn everything you need to know; to change nappies. Like any other job. Even though you enter this parenting process without any schooling, you learn. Trial and error and so on, but I would recommend this to everyone." (Davor)

In countries where fathers' leave use is rare, fathers who take leave begin to understand that childcare and parenting entail a set of learnable skills and, therefore, perceive leave as a period of learning (Valarino, 2017). Fathers in Norway begin perceiving themselves as competent caregivers, attributing this to the time spent on leave when they got to know their child (Brandth and Kvande, 2018).

Fathers pointed out that it is still uncommon for fathers to use leave in Croatia. The majority of fathers said all of the reactions they received were positive, however, a minority was faced with $a$ surprise towards fathers' leave use. Only a few fathers reported on surprised reactions, which ranged from surprise due to a traditional view of childcare to surprise regarding the design of the parental leave scheme. The only father from the sample who used just one month of parental leave said that people in his environment were not aware of the possibility of extending the leave period in case the father uses leave as well:

"In fact, people were surprised because they didn't know this option existed. People confuse maternity leave with the 2 months of parental leave that I have. They weren't aware that there were these two months extra (the quota), independent of the six months that my partner and I agreed she would use." (Tin)

It was mentioned earlier in the article that Croatians believe that mothers should use the entire leave (Jugović, 2016). It is no wonder then that a couple of fathers were also faced with suspicion from some friends and acquaintances over their ability to care for the child independently.

When asked about support they received and relied on during leave, fathers talked about the actual support they had, but they also reflected on the support they would have liked to have had while on leave. Some fathers relied on support from family members, which was either periodical or more frequent. Grandmothers helped with housework, mostly cooking and cleaning, while siblings occasionally helped with childcare. It seems that fathers had someone to rely on when they needed support and were not left entirely alone. However, most fathers were the only ones responsible for caring throughout the leave and only a few relied more frequently on the help and support from family members.

Even though fathers relied mostly on themselves, they also relied on the help and support from the mother/partner. One of the fathers was spending the leave together with the mother since he was on leave for the firstborn, using up his quota, while the mother was on maternity leave for the second-born. This was a unique situation 
among the fathers in the sample and this father saw himself as a helper. However, he also reflected on that role critically, understanding that parenting is a shared responsibility. The experience of being on leave made him rethink his role as a helper and understand that his partner also has a job, suggesting that caring for children should be an equally shared endeavour. Fathers resorted to mothers for informational support, but also relied on mothers for practical support. Such support consisted of preparing lunch or taking over caring for the child when fathers needed rest. Taking turns in childcare seems to have been a form of caring partners employed even before fathers took leave. During mothers' use of leave, fathers would come home from work and take over caring so mothers could get some rest.

To better understand what fathers need while being on leave and get a clearer idea of how to support them more effectively, fathers were asked what else they needed or found useful, but could not get. One of the answers that emerged was the lack of support and contact with other fathers. Karlo was a first time father in his mid-thirties who spent 5 months on leave and engaged in many different activities with the child, but sometimes felt alone:

"Honestly, it would have been useful to have other fathers around me... I would go to swimming lessons for the baby or did some other activity, but there were only mothers there. This was cool in a way, but it was also kind of, you're alone in it, so you can't contribute to all the conversations about childbirth, which is something mothers talk about a lot in that period... it would have been nice to have another father or two around." (Karlo)

Not having other fathers around with whom to share their experiences with has shown to be present in Great Britain as well, where a small number of fathers take leave (O'Brien and Twamley, 2017). Some fathers also expressed a need to spend time with their friends. A need to socialize is prevalent in other research; however, it is often accompanied by fathers reporting feeling isolated or lonely, which was not the case in this research (Duvander et al., 2017; Gíslason, 2017).

Another important answer emerged when discussing what else fathers needed. They expressed a desire for changes in the leave policy. These referred to a desire for an increase in benefit levels, which most of the fathers expressed. A few of them expressed a desire for the possibility of simultaneous use of leave for both partners. Almost all of the fathers discussed the benefit level, saying how it should be as high as their previous income, and they found this to be crucial in increasing the take-up rates among fathers. However, in order to get fathers to use their rights they need to be informed about them:

"I think the scheme is good, but it should be paid in the amount of your salary. I think the duration is also okay considering other things and how it is in other European countries. But you should be informed. There should be giant posters and ads screened on displays in the waiting rooms in all the hospitals where there are children. General practitioners should inform fathers about the leave whenever they come in for any reason, there should be a poster saying they have this option. Without it, who cares if we have the best laws in the world when nobody knows about them... And making the benefit level as high as your salary would be the crucial thing. That would actually mean that fathers are encouraged to take leave." (Martin) 


\section{Attitudes towards family and work}

The last part of the analysis was focused on examining how being on leave reflected on fathers' attitudes towards family and work. When talking about family, parenthood was distinguished from the father-child relationship. Fathers mostly spoke of changes in parenthood perceptions, which happened through several processes. Fathers became more aware of their overall contribution to the household and to childcare in particular. They spoke of supporting the mother, saying how taking leave was one way in which they felt they were supporting their partner. A very important finding observed among a few fathers was that leave made them reflect on their role as a "helper". It made them understand that parenting and taking care of the household is a shared responsibility. The process of re-evaluating his role as a father and understanding what it means to care for children was most evident in the case of Petar, who was the only one of the fathers in this research who was able to spend his leave together with the mother, seeing how they were both using leave for different children:

"I thought there would be less work... It's a difficult job; mothering and taking care of the household... That's why all these things are important (encouraging fathers to be more involved in childcare). Maybe not in some other country, but here they are. If nothing else, it makes you become aware of just how deeply rooted this perception is in your male head... It seems as though I'm coming home from work and helping with something that is my wife's job. And it's not! She has her job." (Petar)

We see that fathers' leave uptake brings about changes in perceptions of the gendered division of work and it is important to advocate for fathers' use of leave, seeing how $42 \%$ of fathers in one Croatian research agree with the statement "My role in caring for the child is mostly that of a helper" (Bijelić, 2011). The experience of leave serves as an eye-opener towards understanding the multiple roles mothers take (Tremblay and Lazzari Dodeler, 2017). Fathers in this research talked about a new outlook on motherhood and how leave contributed to understanding the fact that both parents are earners and must, therefore, also establish a fairer (equal) relation to caring.

When it comes to the father-child relationship, half of the fathers said that leave contributed to the quality of the father-child relationship. Some reported development of closeness with the child, while others talked about establishing a better relationship with the child. Research shows that in order to develop emotional responsibility in their relationship with the child fathers need to spend time alone with the child, which is why the experience of immediate care for the child makes fathers competent and independent in childcare (Doucet, 2017). Fathers in this research support this finding. A first time father who shared leave on an equal basis with the mother said that the experience of being on leave made him a competent parent:

"It did help me (being alone with the child). Now that I see my colleagues, I'm way more independent with him (the child). I don't need my wife. There was even this period when my wife was out of town for work for a week. She wasn't home at all, it was just the two of us, 24-7. And it really wasn't a big deal because I knew what to do and how to do it." (Neven)

It is precisely the experience of being autonomous and independent in childcare that contributes to fathers' sense of competence in childcare, but also to establishing closeness with the child (Wall and Leitão, 2017; Tremblay and Lazzari Dodeler, 2017; Meil et al., 2017; Valarino, 2017). 
Attitudes towards work refer here to both housework and a father's professional life. We see that fathers were actively involved in housework during leave, which mostly consisted of preparing lunch and keeping the household clean and tidy, with only a few fathers occasionally doing the laundry. However, fathers said they felt good about learning new skills concerning housework. For most fathers the distribution of housework between partners was the same before and after leave. This attitude is supported by another research suggesting that the previously established division of housework between partners becomes fixed after having a baby (Almquist and Duvander, 2014).

Referring to their professional life, fathers talked about changes in work perceptions. This meant that fathers became more aware of the amount of time they spend at work. A father of two in his early forties, working in engineering, who spent 4 months of leave for both of his children reflected on the difference in dynamics of being on leave and working full time:

"That was kind of terrible for me; returning to work and understanding how little time I had to spend with my kids. Being on leave makes you used to the idea of always being around, understanding each other, making plans together. Then you start working, leave the kids in kindergarten, return from work, eat something and that's it, you're spent. You spent the best time here (at work). That was a bit of a shock when my leave period finished." (Boris)

Consequently, some fathers started prioritising family over work. This was reflected in establishing and communicating their boundaries at work, not being willing to work overtime and, for one father, opening his own company so that he could work from home after leave and be with his children.

\section{DISCUSSION}

This research provided many insights into the overall experience of taking leave for fathers in Croatia. Fathers in this research share many of their experiences with fathers on leave alone throughout Europe (for an overview, see O'Brien and Wall, 2017.). However, to better understand this research' results in the Croatian context, it is worthwhile reflecting on the prevailing values, which oftentimes seem contradictory. Even though research suggests there has been an ongoing process of retraditionalization in Croatia, there is also an ongoing process of modernity with regard to gender (Sekulić, 2012). A recent study suggests that citizens in Croatia do exhibit more egalitarian attitudes than they did in previous studies, but gender still remains the main predictor of inequality. It seems that a shift towards modernity occurred in the areas of work and education and this is explained by the socialist legacy, which encouraged women to work outside of the home. However, when it comes to gender roles within the household and regarding childcare, a more traditional outlook still prevails. On one hand, respondents believe that women are more capable of raising children by nature $(80 \%)$. On the other, they believe that the man should support the woman's successful career and take on the majority of tasks related to housework and childcare $(78 \%)$. In addition, almost half of the respondents say that caring for the child is an activity that brings most satisfaction in the relationship with their partner. Respondents living in large cities and having higher education were more likely to find satisfaction in childcare (Tomić-Koludrović et al., 2018). European values study showed that people in the city of Zagreb hold more egalitarian values with regard to gender issues than the rest of Croatia (Baloban et al., 2019). These would suggest that fathers in Zagreb would be prone to using leave and those who did would have higher education. 
The sample characteristics are in accordance with the abovementioned values studies. The fathers interviewed were living in dual earner homes and had higher education, as did their partners. These traits coincided with their favourable outlook on using parental leave and caring for their child. Living in Zagreb means that parents have access to additional childcare services that are underdeveloped in some other parts of Croatia, but also receive additional amount of money in the event of childbirth from the City. This puts parents in Zagreb in a more favourable situation concerning their childcare options and choices regarding use of leave. However, even these fathers talked of the lack of support they received as fathers and stressed that the wage replacement rate was too small. This sample can, therefore, be perceived through the lens of a critical case. Even middle-class fathers, living in dual-earner families, having higher education and valuing gender equality, struggled to an extent to exercise their right to leave. What we can learn from fathers in this sample is that leave is used by fathers who are well-informed, who can afford it and those who can rely on family members for support. These findings point towards necessary changes that need to be made in order to encourage more fathers to use leave. Fathers need to be informed, be fairly compensated while on leave and have access to different kind of child benefits. Research from Sweden suggests that "white-collar" fathers receive more formal and informal support to use leave than "blue-collar" fathers (Duvander and Johansson, 2015). Higher socioeconomic status of leave takers is also found in the UK (Koslowski and Kadar-Satat, 2018). Providing a generous replacement rate and securing safety and stability in the workplace in the event of using leave are prerequisites in encouraging fathers from low-income families to engage more in childcare more.
The motivation to use leave for the fathers in this research was most commonly expressed as a desire to be involved in the child's early upbringing, followed by a desire to exercise their right to leave. Croatian fathers perceived taking leave as "normal", similarly to their counterparts in, for example, Iceland and Sweden (Gíslason, 2017; Duvander et al., 2017). They exhibited a sense of entitlement to parental leave and believed that a lack of information and understanding of the leave scheme design kept many fathers from using leave. Fathers in Norway also feel entitled to use leave. However, in their context leave taking is the norm. One father said that to be a good parent you have to take the daddy months (Brandth and Kvande, 2018). It seems that even in countries with a long tradition of fathers using leave, the time spent on leave mostly amounts to the quota. There is a different attitude in Croatia. Out of 11 fathers, eight used leave for four or more months. This is another indication of the fact that these fathers were able to afford taking a considerable amount of time off work, relying on the mother's income, savings or some other source of finance. What it suggests is that leave taking remains inaccessible for fathers living in lower income families, who get by from month to month. Mothers who were interviewed regarding their use of leave in Croatia and Serbia said that their partners didn't use leave because the family couldn't afford to minimise their overall income. These fathers did not even ask for their employer's consent regarding leave use because they feared negative consequences in the workplace (Dobrotić, 2021). Therefore, leave design matters. For example, changes in parental leave benefit in 2017 that increased the upper limit of the benefit have proved to be a decisive element in the decision-making process for two fathers in this research who were affected by this change. Had the benefit stayed the same, they would not have taken leave. 
This behaviour was also reflected in the statistics of fathers who took leave. There was a substantial increase in the number of fathers who took leave in 2018 (Annual Report of the Ombudsperson for Gender Equality of the Republic of Croatia, 2020). Leave scheme's financial aspect is crucial to fathers' uptake (Brandth and Kvande, 2009; O`Brien, 2009; Huerta et al., 2013; Koslowski et al., 2020).

When it comes to exercising their right at the CHIF and the workplace, fathers mostly spoke of uninterrupted exercise. However, they did come across certain issues in exercising their right at the CHIF, which would suggest that on occasion implementing leave rights is uneven. Fathers working in the private sector came across minor issues in the workplace. However, all of them expressed a lot of understanding towards their employer, saying how finding a replacement and reorganising work upon employee's absence is difficult. It should be noted, though, that the fathers in this research were mostly high skilled workers in larger and stable companies. Access to leave use in the workplace is more difficult for fathers (and mothers) in unstable working environments (Dobrotić, 2021). In order to establish fathers as equal carers there needs to be a change in the perception of who is the one providing care within the family. Fathers need to be established as equal carers. Reserving the "daddy quota" was one step in that direction. However, Croatia will still need to comply with the latest EU Directive on work-life balance for parents and carers and implement father's leave by August 2022 (2019).

Experiences while being on leave are threefold. Personal experience of being on leave was somewhat ambiguous, as it made fathers both exhausted and relaxed. Leave was described as a non-stop period, leaving some fathers surprised to learn that childcare required that much attention and effort. However, their overall outlook on the experience was positive and they seemed happy to have learned and acquired new childcare and housework skills. The reactions fathers faced towards their leave-taking were mostly positive, although some faced surprise from friends and acquaintances. People were either surprised since they didn't know that you could extend the overall duration of leave in the event the father uses it as well, or they were surprised to see a father caring for a new-born, due to a perception that mothers are more apt as carers. Only a couple of fathers faced such reactions, but the latter reaction is quite telling of the kind of environment fathers are living in. According to the European values study, in $201743.9 \%$ of all respondents believed that if the mother works, the child suffers. The percentage of those who agreed with the statement was significantly higher in 1999; 62.5\%. However, it has practically stayed the same since 2008 , when it was $44.7 \%$. What is interesting is that more women agreed with the statement than men (Ježovita, 2019). Seeing how fathers in this research seemed intrinsically motivated to use leave and spend time with their children, we might assume there may be some fathers who wish to do the same, but are kept from doing so by the mothers. In her most recent research on using childcare leaves by mothers, Dobrotić (2021) reported on maternal gatekeeping that was reflected in not allowing a smaller number of fathers to exercise their right to leave and care for the child. This kind of attitude would suggest that Croatia needs to invest in changing the societal perception of good motherhood and fatherhood in particular. Changing perceptions of masculinity and fatherhood through public campaigns would enable fathers to involve more in childcare and would also signal to mothers that fathers are competent parents too, if allowed to practice caring for their child.

Support fathers relied on during leave mainly came from their partners, but also 
other family members. Most fathers wished for an increase in benefit levels. The latest increase from 2020 might be important in encouraging more fathers to take leave, although it is still limited for high-earners as the upper ceiling on the parental benefit is $79 \%$ in the average net salary in Croatia (Croatian Bureau of Statistics, 2021). The importance of increasing the benefit replacement rate has been emphasized already several times throughout this article. Without a fair replacement rate, we cannot expect to see a larger number of fathers using leave.

Lastly, we examined fathers' attitudes towards family and work. It was interesting to observe changes in perceptions that have occurred in fathers from this sample, and they are significant with regard to changes in the gendered division of work. Fathers spoke of changes in parenthood perceptions with increasing awareness of their role within the household, both in childcare and in housework. They felt they were supporting their partners by taking leave and reflected on their roles as "helpers". Being "home alone' with the child made fathers understand that parenting is a shared responsibility. In Norway, fathers who take leaves for three months start seeing themselves as equally capable parents who engage in childcare and in housework and increase their sense of respect towards mothering (Kvande and Brandth, 2017). The majority of fathers from this research took "leave alone" for four or more months. This fact indeed added to the changes in perceptions. Fathers believed that leave contributed to the quality of the father-child relationship and it is no wonder then they became more aware of the amount of time they spend at work, not being able to spend time with their child. The changes in the gender perceptions seem to be the most important takeaway from fathers' experiences in the traditionalist Croatian context.

\section{CONCLUSION}

Over the last few decades, and in recent years in particular, there has been an ongoing process of encouraging fathers to engage in childcare more. The purpose of this is to foster gender equality, both in the labour market and in the private sphere. The way in which countries have decided to engage more fathers in childcare is mostly through changes in leave policies, enacting paternity leaves and establishing fathers' quotas. Croatian legislation still does not provide fathers with a right to paternity leave, but it does provide an individual, partially non-transferable right to parental leave (i.e. two-month quota) which most of the fathers do not use. This research was designed to understand what motivates fathers to take leave, their experience regarding the initial decision and procedure of exercising their right to leave and the overall experience of being on leave. Interviews were conducted with 11 middle-class fathers in Croatia's capital Zagreb.

Research results indicate that the fathers in this research are highly motivated and aware of the importance of being involved in childcare, but are also able to afford minimising their income while on leave. The question remains how to get fathers who are not informed, those whose attitudes towards childcare are different and those who would struggle to afford using leave to engage more and use leaves? Firstly, we need a statutory entitlement to paternity leaves, establishing fathers as carers in the workplace, in order to normalize fathers' absence from work due to childcare. Institutionalising this is a prerequisite in establishing fathers as equal carers, as only a dual-earner/ dual carer model may foster gender equality both in the labour market and in the private sphere (Gornick and Meyers, 2001). Secondly, we need financial incentives for fathers to take leave, meaning that their income should not diminish when they choose 
to take some time off work to care for their child. Entitlements that fathers do have in the current state of affairs remain unused because many fathers are not aware of them. For more fathers to use leave, Croatia could also resort to public campaigns which have proven to be successful in other countries (for Canada see Tremblay and Lazzari Dodeler, 2017, for Sweden see Duvander et al, 2017, for Norway see Kvande and Brandth, 2017). Campaigns would also contribute to public opinion changes, as it currently favours mothers as carers, suggesting that mothers should use all or the majority of leave (Jugović, 2016). What is needed is a change of mindset that currently disregards fathers as carers. Changing the perception of fatherhood and masculinity would signal to employers that fathers are equally entitled to use leaves to care for their child(ren). In such a climate, employers would need to adapt to enable fathers to use leave and make necessary arrangements to support their workers in doing so. Right now, we have some employers whose attitudes towards fathers' use of leave are not favourable and workers do not feel empowered to exercise their rights. All these changes are important since children benefit greatly from father's early involvement in childcare; it contributes to the child's cognitive and social development, to their emphatic skills, higher level of self-esteem, to doing better in school and to hold less gender stereotypical views (Lamb, 2010; Dobrotić and Varga, 2018). Additionally, Croatia should invest in and develop childcare services to provide institutional support to parents so they could better manage their family and work obligations and provide parents with a possibility to choose a childcare option that best suits their needs.

This research has a few methodological constraints. The sample consisted of respondents who were middle-class fathers, those reachable mostly through personal contacts, but also more prone (and able) to use the leave within the current leave policy design in Croatia. The sample and the recruitment strategy, therefore, have certain limitations. The data, nonetheless, provide a deeper insight into fathers' motivation and experiences. However, in order to get a more varied insight into fathers' experiences more effort should be invested in reaching those fathers who have a lower socioeconomic status and/or live outside the capital, and who might provide an even more in-depth insight into fathers' experiences while on leave. The method used to collect data, semi-structured interviews, has proven to get fathers to share a lot more than expected. However, focus groups could also be a good way of obtaining data, especially since fathers said they missed knowing other fathers while on leave. Focus groups would be a good way for fathers to come in contact and share their experiences with each other. Additionally, couples interviews could also provide a lot of insight into the family's dynamic with regard to leave use and childcare in general. It would be worthwhile to do interviews with couples where the fathers did and did not use leave and then compare experiences.

These research results can be viewed as a basic insight into fathers' experiences on leave, but more research should be done for the purposes of a more in-depth analysis.

\section{REFERENCES}

Almqvist, A.-L., \& Duvander, A.-Z. (2014). Changes in gender equality? Swedish fathers' parental leave, division of childcare and housework. Journal of Family Studies, 20(1), 19-27. https://doi. org/10.5172/jfs.2014.20.1.19

Aunkofer, S., Meuser, M., \& Neumann, B. (2018). Couples and companies: Negotiating fathers' participation in parental leave in Germany. Revista Española de Sociología, 27(3), 65-81. https:// doi.org/10.22325/fes/res.2018.34

Baloban, J., Črpić, G., \& Ježovita, J. (2019). Vrednote u Hrvatskoj od 1999. do 2018. prema European Values Study. Zagreb: Kršćanska sadašnjost. 
Bijelić, N. (2011). Muškarci i rodna ravnopravnost. Rezultati istraživanja IMAGES - International Men and Gender Equality Survey. Zagreb: CESI - Centar za edukaciju, savjetovanje i istraživanje.

Bungum, B., \& Kvande, E. (2020). Norway country note. In A. Koslowski, S. Blum, I. Dobrotić, G. Kaufman \& P. Moss (Eds.), International Review of Leave Policies and Research 2020. Available at https://www.leavenetwork.org/annual-review-reports/

Boyer, D. (2017). Fathers on leave alone in France: Does part-time parental leave for men move towards an egalitarian model?. In M. O'Brien \& K. Wall (Eds.), Comparative Perspectives on Work-Life Balance and Gender Equality - Fathers on Leave Alone (pp. 183-204). London: Springer Open.

Brandth, B., \& Kvande, E. (2009). Gendered or gender-neutral care politics for fathers. The Annals of the American Academy of Political and Social Science, 624(1), 177-189. https://doi.org/ $10.1177 / 0002716209334119$

Brandth, B., \& Kvande, E. (2018). Fathers' sense of entitlement to ear-marked an shared parental leave. The Sociological Review, 67(5), 11541169. https://doi.org/10.1177/0038026118809002

Braun, V., \& Clarke, V. (2006). Using thematic analysis in psychology. Qualitative Research in Psychology, 3(2), 77-101. https://doi. org/10.1191/1478088706qp063oa

Bünning, M. (2015). What happens after the 'Daddy months'? Fathers' involvement in paid work, childcare, and housework after taking parental leave in Germany. European Sociological Review, 31(6), 738-748. https://doi.org/10.1093/esr/jcv072

Burnett, S. B., Gatrell, C. J., Cooper, C. L., \& Sparrow, P. (2013). Fathers at work: A Ghost in the organizational machine. Gender, Work and Organization, 20(6), 632-646. https://doi.org/10.1111/ gwao. 12000

Croatian Bureau of Statistics. (2021). Average monthly net and gross earnings per employee for June 2021. Available at https://www.dzs.hr/Hrv_Eng/ publication/2021/09-01-01_06_2021.htm

Directive (EU) 2019/1158 of the European Parliament and of the Council of 20 June 2019 on work-life balance for parents and carers and repealing Council Directive 2010/18/EU. Official Journal of the European Union L 188/79. Available at http://data.europa.eu/eli/dir/2019/1158/oj

Dobrotić, I. (2015). Politike usklađivanja obiteljskih obaveza i plaćenog rada i položaj roditelja na tržištu rada. Revija za socijalnu politiku, 22(3), 353-374. https://doi.org/10.3935/rsp.v22i3.1258
Dobrotić, I. (2021). „Rastuća (ne)vidljiva većina“? Nesigurna i netipična zaposlenost i roditeljstvo". Available at https://www.incare-pyc.eu/wp-content/uploads/2021/02/InCARE-report-final-web. pdf

Dobrotić, I., \& Blum, S. (2020). A social right? Access to leave and its relation to parents' labour market position. In P. Moss, A.-Z. Duvander \& A. Koslowski (Eds.), Parental Leave and Beyond. Recent International Developments, Current Issues and Future Directions (pp. 261-280). Bristol: Policy Press.

Dobrotić, I., \& Varga, M. (2018). Zašto su važni očevi dopusti i kvote? Komparativni pregled shema dopusta za očeve u europskim zemljama te čimbenika i učinaka njihova korištenja. Revija za sociologiju, 48(2), 209-237. https://doi. org/10.5613/rzs.48.2.4

Doucet, A. (2017). The ethics of care and the radical potential of fathers 'home alone on leave'. In M. O’Brien \& K. Wall (Eds.), Comparative Perspectives on Work-Life Balance and Gender Equality - Fathers on Leave Alone (pp. 11-28). London: Springer Open.

Duvander, A.-Z., \& Johansson, M. (2015). Parental leave use for different fathers: A study of the impact of three Swedish parental leave reforms. In G. B. Eydal \& T. Rostgaard (Eds.), Fatherhood in the Nordic Welfare states: Comparing care policies and practice (pp. 347-370). Bristol: Policy Press

Duvander, A.-Z., Haas, L., \& Thalberg, S. (2017). Fathers on leave alone in Sweden: Toward more equal parenthood?. In M. O'Brien \& K. Wall (Eds.), Comparative Perspectives on Work-Life Balance and Gender Equality - Fathers on Leave Alone (pp. 125-145). London: Springer Open.

Farré, L. (2016). Parental leave policies and gender equality: A Survey of the literature. Estudios de economía aplicada, 34(1), 45-60. Available at https://www.redalyc.org/pdf/301/30143731003. pdf

Flyvbjerg, B. (2006). Five misunderstandings about case-study research. Qualitative Inquiry, 12(2), 219-245. https://doi.org/10.1177/1077800 405284363

Geisler, E., \& Kreyenfeld, M. (2011). Against all odds: Fathers' use of parental leave in Germany. Journal of European Social Policy, 21(1), 88-99. https://doi.org/10.1177/0958928710385732

Gíslason, I. V. (2017). Fathers on leave alone in Iceland: Normal paternal behaviour?. In M. O'Brien \& K. Wall (Eds.), Comparative Perspectives on Work-Life Balance and Gender Equality- 
Fathers on Leave Alone (pp. 147-162). London: Springer Open.

Gornick J. C., \& Meyers M. K. (2001). Building the dual earner/dual carer society: policy developments in Europe. Working paper No. 82. Available at http://aei.pitt.edu/9143/1/GornickMeyers.pdf

Haas, L., \& Hwang, P. (2008). The impact of taking parental leave on fathers' participation in childcare and relationships with children: Lessons from Sweden. Community, work \& family, 11(1), 85104. https://doi.org/10.1080/13668800701785346

Huerta, M.-C., Adema, W., Baxter, J., Han, W.-J., Lausten, M., Lee, R., \& Waldfogel, J. (2013). Fathers' leave, fathers' involvement and child development: Are they related? Evidence from four OECD Countries. OECD Social, Employment and Migration Working Papers, 140. Paris: OECD Publishing.

Ježovita, J. (2019). Komparativni pregled odgovora na pitanja $u$ anketi europskog istraživanja vrednota (EVS) - 1999., 2008. i 2017. Bogoslovska smotra, 89(2), 225-329. https://hrcak.srce.hr/223155

Jugović, I. (2016). Beliefs about the gender division of parental leave and characteristics associated with them. Revija za socijalnu politiku, 23(3), 359-382. https://doi.org/10.3935/rsp.v23i3.1292

Korsvik, T. R., \& Warat, M. (2016). Framing leave for fathers in Norway and Poland: Just a matter of gender equality?. NORA - Nordic journal of feminist and gender research, 24(2), 110-125. https://doi.org/10.1080/08038740.2016.1182588

Koslowski, A., \& Kadar-Satat, G. (2010). Fathers at work: Explaining the gaps between entitlement to leave policies and uptake. Community, Work \& Family, 22(2), 129-145. https://doi.org/10.108 0/13668803.2018.1428174

Koslowski, A., Blum, S., Dobrotić, I., Kaufman, G., \& Moss, P. (2020). International Review of Leave Policies and Research 2020. Available at https:// www.leavenetwork.org/annual-review-reports/ archive-reviews/

Kvande, E., \& Brandth, B. (2017). Fathers on leave alone in Norway: Changes and continuities. In M. O'Brien \& K. Wall (Eds.), Comparative Perspectives on Work-Life Balance and Gender Equality - Fathers on Leave Alone (pp. 29-44). London: Springer Open.

Lammi-Taskula, J. (2017). Fathers on leave alone in Finland: Negotiations and lived experiences. In M. O'Brien \& K. Wall (Eds.), Comparative Perspectives on Work-Life Balance and Gender Equality-Fathers on Leave Alone (pp. 89-106). London: Springer Open.
McKay, L., \& Doucet, A. (2010). Without taking her leave away: a Canadian case study on couple's decisions on father's use of paid parental leave. Fathering: A journal of theory, research and practice about men as fathers, 8(3), 300-320. https://doi.org/10.3149/fth.0803.300

Maternity and Parental Benefits Act (Zakon o rodiljnim i roditeljskim potporama). Narodne novine, br. 54/2013, 59/2017, 37/2020.

Meil, G., Romero-Balsas, P., \& Rogero-García, J. (2017). Fathers on leave alone in Spain: 'Hey, I want to be able to do it like that, too'. In M. O'Brien \& K. Wall (Eds.), Comparative Perspectives on Work-Life Balance and Gender Equality -Fathers on Leave Alone (pp. 107-124). London: Springer Open.

Nepomnyaschy, L., \& Waldfogel, J. (2007). Paternity leave and fathers' involvement with their young children - Evidence from the American EclsB Community. Work and Family, 10(4), 427-453. https://doi.org/10.1080/13668800701575077

O'Brien, M. (2009). Fathers, parental leave policies, and infant quality of life: International perspectives and policy impact. The annals of the American academy, 624(1), 190-213. https://doi. org $/ 10.1177 / 0002716209334349$

O'Brien, M., \& Twamley, K. (2017). Fathers taking leave alone in the UK - A gift exchange between mother and father?. In M. O'Brien \& K. Wall (Eds.), Comparative Perspectives on Work-Life Balance and Gender Equality - Fathers on Leave Alone (pp. 163-182). London: Springer Open.

O’Brien, M., \& Wall, K. (Eds.). (2017). Comparative Perspectives on Work-Life Balance and Gender Equality - Fathers on Leave Alone. London: Springer Open.

Ombudsperson for gender equality. (2020). Annual Report of the Ombudsperson for Gender Equality of the Republic of Croatia for 2019. Available at https://www.prs.hr/attachments/article/2894/ IZVJESCE_O_RADU_ZA_2019_Pravobraniteljice_za_ravnopravnost_spolova.pdf

Rege, M., \& Solli, I. F. (2013). The impact of paternity leave on fathers' future earnings. Demography, 50(1), 2255-2277. https://doi.org/10.1007/ s13524-013-0233-1

Sekulić, D. (2012). Društveni okvir i vrijednosni sustav. Revija za sociologiju, 42(3), 231-275. https:// doi.org/10.5613/rzs.42.3.1

Tanaka, S., \& Waldfogel, J. (2007). Effects of parental leave and work hours on fathers' involvement with their babies - Evidence from the millennium cohort study, Community, 
Work and Family, 10(4), 409-426. https://doi. org/10.1080/13668800701575069

Tomić-Koludrović, I., Petrić, M., Puzek, I., \& Zdravković, Ž. (2018). Rodni stavovi i prakse u Hrvatskoj - Izvještaj o kvantitativnim rezultatima projekta GENMOD. Split: Institut društvenih znanosti Ivo Pilar.

Tremblay, D.-G., \& Lazzari Dodeler, N. (2017). Fathers on leave alone in Quebec (Canada): The Case of innovative, subversive and activist fathers!. In M. O'Brien \& K. Wall (Eds.), Comparative Perspectives on Work-Life Balance and Gender Equality - Fathers on Leave Alone (pp. 69-88). London: Springer Open.

Valarino, I. (2017). Fathers on leave alone in Switzerland: Agents of social change?. In M. O'Brien \& K. Wall (Eds.), Comparative Perspectives on Work-Life Balance and Gender Equality - Fathers on Leave Alone (pp. 205-230). London: Springer Open.
Valarino, I., \& Gauthier, J.-A. (2016). Paternity leave implementation in Switzerland: A challenge to gendered representations and practices of fatherhood?. Community, Work \& Family, 19(1), 1-20. https://doi.org/10.1080/13668803.2015.1023263

Wall, K., \& Leitão, M. (2017). Fathers on leave alone in Portugal: Lived experiences and impact of forerunner fathers. In M. O'Brien \& K. Wall (Eds.), Comparative Perspectives on Work-Life Balance and Gender Equality - Fathers on Leave Alone (pp. 45-68). London: Springer Open.

Wall, K., \& O’Brien, M. (2017). Discussion and conclusions. In M. O'Brien \& K. Wall (Eds.), Comparative Perspectives on Work-Life Balance and Gender Equality - Fathers on Leave Alone (pp. 257-266). London: Springer Open.

Whitehouse, G., Diamond, C., \& Baird, M. (2007). Fathers' use of leave in Australia. Community, Work and Family, 10(4), 387-407. https://doi. org/10.1080/13668800701575002 


\title{
Sažetak
}

\section{OČEVI NA DOPUSTU: ISKUSTVA OČEVA SREDNJEG DRUŠTVENOG SLOJA NA RODITELJSKOM DOPUSTU U GRADU ZAGREBU}

\author{
Mirna Varga \\ Udruga za kreativni socijalni rad \\ Zagreb, Hrvatska
}

Reforme roditeljskih dopusta usmjerene na uključivanje većeg broja očeva u brigu o djeci započele su 1970-ih, međutim broj očeva koji su koristili roditeljske dopuste povećao se tek 1990-ih kada su skandinavske države počele uvoditi kvote za očeve, odnosno očeve dopuste. Te su kvote periodi dopusta namijenjeni isključivo očevima te u slučaju neiskorištenosti od strane oca propadaju. Hrvatska je uvela dvomjesečnu kvotu za očeve tek 2013. Iako reforma nije doprinijela značajnom povećanju broja očeva koji koriste dopuste, u Hrvatskoj uvijek imamo određeni stabilan, iako mali, broj očeva koji koriste dopuste. Namjera ovog rada je pružiti uvid u iskustva očeva na roditeljskom dopustu u Hrvatskoj. Intervjuima s 11 očeva srednjeg društvenog sloja u Gradu Zagrebu dobiven je uvid u motivaciju očeva za korištenjem dopusta, njihova iskustva $u$ vidu donošenja odluke i postupku ostvarivanja prava na dopust te njihova iskustva tijekom samog korištenja roditeljskog dopusta. Rezultati pokazuju kako su očevi bili jako motivirani koristiti svoje pravo na dopust i provesti vrijeme s djetetom. Uglavnom su koristili duže dopuste (više od 3 mjeseca) te im je iskustvo bivanja samih s djetetom omogućilo stjecanje novih vještina u brizi za djecu i za kućanstvo, ali ih je i potaknulo da promisle o svojem odnosu prema poslu i obitelji.

Ključne riječi: politike roditeljskih dopusta, roditeljski dopust, očeve kvote, iskustva očeva, Hrvatska. 